DOI

\title{
КОРЕКЦІЯ ДИСБІОЗУ КИШЕЧНИКА У ХВОРИХ, ОПЕРОВАНИХ З ПРИВОДУ РАКУ ШЛУНКА
}

\author{
๑А. В. Русин, Н. В. Бедей, Н. М. Маляр-Газда, О. М. Одошевська, Е. С. Хома \\ Ужгородський національний університет
}

РЕЗЮМЕ. У роботі представлені результати зміни показників кишкової мікрофлори товстої кишки на різних стадіях пухлинного процесу до та після лікування. Особливо важливі вчасне розпізнання та терапія кишкового кандидозу, як профілактика системного та генералізованого кандидозу у пацієнтів із груп ризику, до яких насамперед належать пацієнти, які отримують протипухлинну променеву та/або хіміотерапію. Після лікування у хворих на рак шлунка спостерігали зменшення дисбіозу товстої кишки, а також зменшення кишкового кандидозу, що дозволяє поліпшити якість життя пацієнтів.

КЛЮчОВІ СЛОВА: рак шлунка, дисбіоз товсої кишки, інтоксикаційний синдром, кишковий кандидоз.

Вступ. Рак шлунка (РШ), незважаючи на стійке зниження рівня захворюваності, $\epsilon$ однією 3 найпоширеніших пухлин як в Україні, так і в інших країнах світу, щорічно він $\epsilon$ причиною загибелі більш ніж 600 тис. хворих. Рівень захворюваності на РШ в країнах Євросоюзу становить 20 випадків на 100 тис. населення, смертності - 16 на 100 тис. населення $[3,5]$. В Україні у 2011 р. зареєстровано 25,32 випадку захворювання на 100 тис. населення, 62 \% хворих із вперше встановленим діагнозом померли протягом першого року, тому ця патологія залишається однією з найважливіших медичних та соціально-економічних проблем [6]. Результати лікування поширеного РШ (III-IV стадії) не можна вважати задовільними, оскільки, за даними більшості авторів, лише близько 15-25 \% хворих переживають 5-річний термін [7]. На момент встановлення діагнозу 70 \% пацієнтів у нашій країні не підлягають оперативному лікуванню у зв'язку з поширеністю пухлинного процесу, хворим цієї групи проводять поліхіміотерапію.

Необхідно зазначити, що перебіг пухлинного процесу супроводжується формуванням синдрому ендогенної інтоксикації та вторинної імунної недостатності. Ендотоксикоз, як і будь-який токсикоз, - це складний каскадний стадійний, здатний до прогресування генералізований процес, який обумовлений накопиченням в кров'яному руслі токсичних речовин в концентраціях, що переважають функціональні можливості природних систем детоксикації. Ці пошкодження, в свою чергу, суттєво модифікують структурно-функціональний стан клітинних та субклітинних мембран, викликають другу хвилю інтоксикації та створюють замкнуте коло даного критичного стану. Тяжкість ендогенної інтоксикації $\epsilon$ непрямим критерієм тяжкості загального стану хворих з різними патологічними процесами.

На сьогодні в літературі немає однозначної інформації про те, чи можливо за допомогою ко- рекції мікробіологічного складу кишечника зменшити ендогенну інтоксикацію.

В сучасній літературі розрізняють два види дисбіозу - тонкокишковий та товстокишковий, їх також можна розглядати як один загальний синдром - дисбіоз кишечника.

Мікрофлору кишечника поділяють на облігатну - неспороутворюючі анаероби (біфідо- і лактобактерії, бактероїди), що постійно входять у склад нормальної мікрофлори. Питома вага біфідобактерій та бактероїдів складає до 98 \% мікрофлори кишечника; факультативну - анаеробні бактерії (кишкова паличка, стрептокок тощо), які часто зустрічаються у здорових людей, але $\epsilon$ умовно патогенними. Питома вага складає близько 1-4 \%; транзиторну (залишкову, випадкову, алохтонну) мікроби, які зустрічаються в кишечнику спорадично (стафілококи, протей, клостридії, дріжджоподібні гриби, клебсіели та ін.), питома вага яких складає 0,01-0,001 \% [2].

Особливо важливе вчасне розпізнання та терапія кишкового кандидозу, як профілактика системного та генералізованого кандидозу у пацієнтів із груп ризику, до яких насамперед належать пацієнти, які отримують протипухлинну променеву та/а6о хіміотерапію тощо [4].

Деякі автори пропонують розрізняти в мікробіоценозі товстої кишки цукроволітичні бактерії (біфідо- та лактобактерії, ентерококи), безумовно корисні для людини; протеолітичні бактерії (бактероїди, протей, клостридії, деякі штами кишкової палички), які в деяких випадках можуть стати шкідливими для здоров'я людини [1].

Кишкова мікрофлора, на думку ряду дослідників, $\epsilon$ своєрідним "органом», що виконує такі важливі функції, як:

- детоксикаційна (інактивація ентерокінази, лужної фосфатази);

- колонізаційна резистентність організму (активація імунної системи, міжмікробний антагонізм); 
Огляди літератури, оригінальні дослідження, погляд на проблему

- ферментативна (гідроліз продуктів метаболізму білків, вуглеводів, ліпідів);

- синтетична (синтез вітамінів, гормонів та інших біологічно активних речовин);

- травна (підвищення фізіологічної активності травного тракту);

- антианемічна, антирахітична (покращення всмоктування заліза, кальцію, вітаміну D);

- імуномодулювальна (регуляція функцій гуморального і клітинного імунітету, стимуляція синтезу імуноглобулінів, $\alpha$-інтерферону, IL-2);

- антихолестеринемічна (декон'югація солей жовчних кислот, асиміляція та преципітація холестерину);

- антимутагенна та антиканцерогенна [2].

Зниження детоксикаційної функції мікрофлори ШКТ призводить до того, що кров із токсинами із кишечника надходить ворітною веною в печінку, збільшуючи навантаження на їі ферментні системи, призводячи до метаболічних та структурних пошкоджень гепатоцитів. Мікрофлора ШКТ, як «екстракорпоральний орган» детоксикації, подібно до печінки, охороняє організм від токсичних впливів продуктів метаболізму.

На теперішній час в вітчизняній та закордонній літературі ми не знайшли досліджень з корекції дисбіозу кишечника у хворих на рак шлунка.

Необхідно зазначити, що проблема зниження пухлинної інтоксикації та корекції кишкового дисбіозу з метою проведення повноцінних курсів хіміотерапії та покращення якості життя пацієнтів з онкопатологією є однією з актуальних проблем клінічної онкології сьогодення.

Мета дослідження. Вивчити зміни показників кількісного та якісного стану мікрофлори товстої кишки у хворих на рак шлунка до та після хірургічного лікування.

Матеріал і методи дослідження. Ми провели спостереження у 100 пацієнтів з верифікованим діагнозом РШ, які перебували на лікуванні у Закарпатському обласному онкологічному диспансері за період 2013-2015 рр. За стадіями патологічного процесу пацієнти були поділені наступним чином: у 15 пацієнтів була II стадія, у 44 - III стадія, у 41 IV стадія пухлинного процесу відповідно.

Усім обстежуваним проводили загальноклінічні аналізи крові на момент первинного поступлення в стаціонар для діагностики та лікування.

Дослідження видового та кількісного складу мікрофлори товстої кишки (виконували дворазово: при поступленні та через (34 \pm 3 ) доби) проводили методом посіву десятикратних розведень $\left(10^{-1}-10^{-9}\right)$ на стандартний набір елективних та диференційно-діагностичних живильних середовищ для виділення аеробних та анаеробних мікроорганізмів.
Взяття калу проводили в стерильний посуд, що герметично закривається (посуд надавала мікробіологічна лабораторія). 3бір калу проводили дотримуючись стерильності. Пробу для дослідження брали із останньої порції фекалій. Кількість зібраного матеріалу становила 1-3 г (о6'єм фекалій приблизно дорівнював насінині бобу). Аналіз на дисбіоз забирали у хворих на рак шлунка при поступленні.

Ступінь дисбіозу кишечника оцінювали за класифікацією Куваєвої І. Б., Ладодо К. С. (1991 р.):

1 ступінь характеризується зниженням на 1-2 рівні кількості біфідо- та лактобактерій;

2 ступінь характеризується зниженням на 3-4 рівні кількості біфідо- та лактобактерій із підвищенням кількості умовно-патогенної флори стафілококів, протею; умовно-патогенна флора може мати гемолітичні властивості;

3 ступінь характеризується значним зниженням кількості анаеробів (біфідо- та лактобактерій) та поступовим підвищення кількості аеробів; умовно-патогенна флора набуває агресивних властивостей;

4 ступінь характеризується значними змінами співвідношень облігатних та факультативних мікроорганізмів, різким зниженням функцій кишкової флори, активацією умовно-патогенної флори.

Для лікування пацієнтів, у яких було виявлено кишковий дисбіоз, застосовували: препарати Ентерожерміна - натще 30 діб, Ентеросгель 1 столова ложка 3 рази/добу - за дві години після їди або прийому ліків або за дві години до прийому їжі, Есенціале Форте - 1 капсула 3 рази/добу 20 діб, а також тим пацієнтам, у яких було виявлено кандиду - Флюконазол - 100 мг 1 раз/добу 10 діб.

Результати й обговорення. При вивченні вікового складу пацієнтів ми виявили: пацієнтів віком 21-39 років - (10\%), 40-59 років - (55 \%) та старших за 60 років - (35\%). Серед них чоловіків було 67 (67\%), а жінок 33 (33\%).

Результати клінічних спостережень та бактеріологічних досліджень показали, що дисбіоз товстої кишки виявили у $96 \%$ хворих на рак шлунка. Патологічні зсуви у складі облігатної мікрофлори, що характеризувалися дефіцитом або повним зникненням біфідо- та лактобактерій, ми спостерігали у 94 (97,9\%) та 89 (92,7\%) хворих. Зміни в складі представників колі-флори з дисбалансом в кількісному та якісному відношенні були у $72(75,0 \%)$ та 54 (56,2 \%) хворих, при цьому з проявами агресії - гемоліз еритроцитів - у 37 (38,5 \%) хворих. Умовно патогенну кишкову флору виявили у 39 (40,6\%) хворих. 
Огляди літератури, оригінальні дослідження, погляд на проблему

Появу в мікробному складі більше допустимої норми мікроорганізмів роду Proteus спостерігали у 14 (1,6\%) хворих та грибів роду Candida -y $27(28,1 \%)$ хворих, появу золотистого стафілококу -у $18(18,8 \%)$ хворих. у більшості хворих - 54 (56,3 \%) - на рак шлунка констатовано асоціативний дисбіоз кишечника, обумовлений мікробною асоціацією з 2-3 представників умовно патогенної флори (табл. 1).

Таблиця 1. Зміни мікрофлори товстої кишки у хворих на РШ

\begin{tabular}{|c|c|c|}
\hline Показник & Норма & $\mathrm{N}=96$ \\
\hline Біфідобактерії < $10^{7}$ & $10^{7}$ і вище & $89(97,9 \%)$ \\
\hline Лактобактерії < $10^{6}$ & $10^{6}$ і вище & $72(75,0 \%)$ \\
\hline $\begin{array}{c}\text { Знижена загальна кількість } \\
\text { Е. coli }\end{array}$ & $300-400$ млн/г \\
\hline Слабоферментативна Е.coli & до $10 \%$ & $54(56,2 \%)$ \\
\hline Гемолітична кишкова паличка & немає & $37(38,5 \%)$ \\
\hline $\begin{array}{c}\text { Умовно-патогенні } \\
\text { ентеробактерії }\end{array}$ & немає & $39(40,6 \%)$ \\
\hline $\begin{array}{c}\text { Гриби роду Сапdida } \\
\text { Кількість патогенного } \\
\text { стафілококу }\end{array}$ & до $10^{3}$ & $18(18,8 \%)$ \\
\hline Кількість Рготеus & до $10^{3}$ & $14(14,6 \%)$ \\
\hline
\end{tabular}

Таким чином, у більшості хворих на рак шлунка виявлено стійкі патологічні зсуви мікроекології товстої кишки, що характеризувалися зміною загальної кількості типових кишкових паличок, появою гемолітичних кишкових паличок, дефіцитом основних представників мікробного пейзажу - біфідобактерій та лактобактерій, збільшенням кількості гнилісних та грибкових бактерій.

Формування дисбіозу товстої кишки у хворих на рак шлунка можна пояснити зривом адаптаційних, захисних, компенсаторних механізмів, при якому макроорганізм не встигає виробляти ефективні захисні механізми від токсичних субстратів, в результаті чого виникають дисбіотичні порушення кишечника різного ступеня тяжкості.

Порушення видового стану нормальної мікрофлори за участю грибів Candida $€$ характерним при дисбіозі кишечника у хворих на рак шлунка, що підтверджується високим відсотком їх присутності в наших спостереженнях $-28,1 \%$.

У таких пацієнтів часто відмічається пригнічення всіх показників імунітету. Як відомо, існує тісний зв'язок між станом імунітету та кандидозом. Кандидоз може бути як наслідком, так і причиною імунної недостатності, що сприяє генералізації кандидозної інфекції. Наведені вище дані дають підставу стверджувати, що застосування імунокоректорів, як і антифунгінальних засобів, $\epsilon$ обов'язковим в корекції дисбіотичних порушень у даної категорії пацієнтів.

У структурі кишкового дисбіозу у наших хворих певне місце займають дисбіотичні порушення, обумовлені бактеріями роду Proteus. Дисбактеріоз товстої кишки, обумовлений бактеріями роду Proteus, ми виявили у 14,6 \% хворих.

У пацієнтів, хворих на рак шлунка ІІ ст., дисбіозу не було виявлено у 4-х (26,7 \%) пацієнтів, дисбіоз І ступеня був у 9 (60\%) хворих та дисбіоз ІІ ступеня - у 2 (13,3 \%) хворих. У пацієнтів з ІІІ ст. РШ дисбіозу не виявлено у 1 (2,3 \%) пацієнта, дисбіоз І ступеня виявлено у 14 (31,8 \%) хворих, дисбіоз II ступеня - у 23 (52,3 \%) хворих, дисбіоз III ступеня - у чотирьох $(9,1 \%)$ хворих та дисбіоз IV ступеня - у двох (4,5\%) хворих. У пацієнтів з IV ст. РШ було виявлено дисбіоз І ступеня -у 12 (29,3 \%) пацієнтів, дисбіоз ІІ ступеня - у 14 (34,1 \%) пацієнтів, дисбіоз III ступеня -у 10 (24,4 \%) хворих та дисбіоз IV ступеня -у 5 (12,2 \%) пацієнтів (табл. 2).

3 таблиці 2 чітко видно, що при збільшенні стадії раку шлунка збільшується ступінь дисбіотичних змін у товстій кишці. Цей факт, можливо, погіршує перебіг основного захворювання та якість жит-

Таблиця 2. Зміни мікрофлори товстої кишки у хворих на рак шлунка

\begin{tabular}{|c|c|c|c|c|c|c|c|c|c|c|c|c|c|c|c|}
\hline $\begin{array}{c}\text { Досліджувані } \\
\text { параметри }\end{array}$ & \multicolumn{5}{|c|}{ Пацієнти з II ст. РШ } & \multicolumn{5}{c|}{ Пацієнти з III ст. РШ } \\
(n=44) & \multicolumn{5}{c|}{ Пацієнти з IV ст. РШ } \\
(n=41)
\end{tabular}


Огляди літератури, оригінальні дослідження, погляд на проблему

тя таких пацієнтів. Саме тому вищеперераховані зміни кількісного та якісного складу мікрофлори товстої кишки вимагають корекції: збільшення кількості біфідо- та лактобактерій та зменшення кількості умовно-патогенних бактерій. Це говорить про те, що кожен пацієнт повинен мати індивідуальну схему лікування дисбіотичних явищ у кишечнику.

Після лікування спостерігали наступне: зменшилася кількість пацієнтів із низькою кількістю біфідо- та лактобактерій, а саме на 34,4\% та 28,1 \% проти 97,9 \% та 92,7 \% до лікування, загаль- на кількість ешерихій колі зменшилася з 75,0 \% на 21,9 \%. Слабоформентативна Е. coli виявлена у 19,8 \% проти 56,2 \% до лікування. Гемолітична E. coli зменшилась із 38,5 \% до лікування на 17,7 \% після лікування. Умовно патогенні ентеробактерії зменшились після лікування із 40,6 \% на 14,6\%. Гриби роду Candida суттєво зменшились із 28,1\% на 3,1 \%. Кількість патогенного стафілококу та Proteus залишилась майже на такому рівні, як були до лікування, так як вищеперераховане лікування не впливало на зменшення їх кількості (табл. 3).

Таблиця 3. Зміни мікрофлори товстої кишки у хворих на РШ після лікування

\begin{tabular}{|c|c|c|}
\hline Показник & Норма & $\mathrm{N}=96$ \\
\hline Біфідобактерії < $10^{7}$ & $10^{7}$ і вище & $27(34,4 \%)$ \\
\hline Лактобактерії < $10^{6}$ & $10^{6}$ і вище & $21(21,9 \%)$ \\
\hline Знижена загальна кількість E. coli & $300-400 \mathrm{млн/г}$ & $19(19,8 \%)$ \\
\hline Слабоферментативна E. coli & до $10 \%$ & $17(17,7 \%)$ \\
\hline Гемолітична кишкова паличка & немає & $3(3,1 \%)$ \\
\hline Умовно-патогенні ентеробактерії & немає & $17(17,7 \%)$ \\
\hline Гриби роду Саndida & до $10^{3}$ & $13(13,5 \%)$ \\
\hline Кількість патогенного стафілококу & до $10^{3}$ & до $10^{4}$ \\
\hline Кількість Ргоteus & & \\
\hline
\end{tabular}

Ми спостерігали зменшення кількості пацієнтів із дисбіозом кишечника після лікування, а саме: серед пацієнтів з ІІ ст. РШ 11 пацієнтів не мали дисбіотичних порушень і тільки четверо мали дисбіоз І ступеня, дисбіозу ІІ ступеня виявлено не було; серед пацієнтів з ІІІ ст. РШ 29 - не мали дисбіозу, дисбіоз І ступеня мав 1 пацієнт, дисбіоз II ступеня - 11 пацієнтів, дисбіоз III ступеня - 2 пацієнти та дисбіоз IV ступеня - 1 хворий; серед пацієнтів з IV ст. РШ дисбіозу після лікування не було виявлено у 27 чоловік, дисбіоз І ступеня спостерігали у 1 пацієнта, дисбіоз II ступеня - у 6, дисбіоз III ступеня - у 4 та дисбіоз IV ступеня залишився у 3 хворих (табл. 4).

Таблиця 4. Зміни мікрофлори товстої кишки у хворих на рак шлунка після лікування

\begin{tabular}{|c|c|c|c|c|c|c|c|c|c|c|c|c|c|c|}
\hline $\begin{array}{c}\text { Досліджувані } \\
\text { параметри }\end{array}$ & \multicolumn{5}{|c|}{ Пацієнти з II ст. РШ } & \multicolumn{5}{c|}{ Пацієнти 3 III ст. РШ } \\
(n=15)
\end{tabular}

Висновки. 1. У більшості пацієнтів з ІІ стадією РШ мікрофлора товстої кишки після лікування була переважно без порушень (73,3 \%), виявлено також та дисбіоз І тупеня (26,7 \%).

2. У хворих з III стадією РШ мікрофлора товстої кишки повернулася до норми більше ніж у 60 \% пацієнтів, та переважав дисбіоз товстої кишки середнього ступеня (II).

3. У пацієнтів IV стадією РШ мікрофлора тов- стої кишки повернулася до норми більш ніж у 65 \% пацієнтів, переважав дисбіоз товстої кишки середнього та тяжкого ступенів (II, III та IV).

Перспективи подальших досліджень. Наші наступні дослідження будуть спрямовані на дослідження та виявлення дисбіозу товстої кишки у хворих з раком яєчників та раком легень. А також на пошук оптимальних схем лікування дисбіозу товстої кишки у даних онкохворих. 
Огляди літератури, оригінальні дослідження, погляд на проблему

\section{ЛІТЕРАТУРА}

1. Барановский А. Ю. Дисбактериоз и дисбиоз кишечника / А. Ю. Барановский, Э. Я. Кондрашина. - СПб., 2000. - C. 209.

2. Бондаренко В. М. Дисбактериоз кишечника как клинико-лабораторный синдром: современное состояние проблемы / В. М. Бондаренко, Т. В. Мацулевич. М. : ГЭОТАР - Медиа, 2007. - С. 304.

3. Горбунов В. А. Качество жизни онкологических больных / В. А. Горбунов, В. В. Бредер // IV Ежегодная Рос. Онколог. Конф. : труды конф. - М., 2000. С. 125-127.

4. Златкина А. Р. Кандидоз кишечника как новая проблема гастроэнтерологи / А. Р. Златкина, В. А. Иса- ков, И. О. Иваннтков // Российский журнал гастроэнтерологии, гепатологии, колопроктологии.-2001.- № 6.C. 33-38.

5. Рак желудка. На пути к решению проблемы / Г. В. Бондарь, А. Ю. Попович, В. Г. Бондарь [и др.] // Хірургія України. - 2006. - № 17. - С. 8-12.

6. Рак желудка: профілактика, діагностика и лечение на современном этапе / Г. В. Бондарь, Ю. В. Думанский, А. Ю. Попович [и др.] // Онкологія. - 2006. - Т. 8, № 2. - С. 171-175.

7. Bendell J. Latest data on the treatment of upper gastrointestinal cancers / J. Bendell // ASCO Education Book. - 2008. - P. 184-190.

\title{
CORRECTION OF INTENTSTINAL DYSBIOSIS IN PATIENTS WHO UNDERWENT SURGERY BECAUSE OF STOMACH CANCER
}

\author{
@A. V. Rusyn, N. V. Bedey, N. M. Maliar-Hazda, O. M. Odoshevska, E. S. Khoma \\ Uzhhorod National University
}

SUMMARY. The paper presents the results of changes of the intestinal microflora of the large intestine in different stages of tumor before and after treatment. Especially important to the timely identification and treatment of intestinal candidosis, as prevention of systematic and generalized candidosis in patients with high-risk groups, which primarily include patients who take out radial anti-tumor and / or chemotherapy. After treatment in patients with stomach cancer there was observed a reduced number of dysbiosis colon and reduce intestinal candidosis that facilitates the quality of life of patients.

KEY WORDS: stomach cancer, colon dysbiosis thick, intoxication syndrome, intestinal candidosis.

Отримано 12.07 .2016 